\title{
Mexican local suppliers in home appliance value chains
}

\author{
Volumen XIX No (1). Enero-Junio 2019. Pág. 49-61
}

ISSN: 0121-1048 IMPRESO ISSN: 2422-3220 EN LÍNEA

\author{
Velarde-Moreno, Oscar \\ Universidad Autónoma de \\ Sinaloa, Profesor investigador, \\ Circuito Interior Oriente SN, Cd \\ Universitaria, Privada del Real, \\ 80040 Culiacán Rosales, Sin. \\ Oevelarde@uas.edu.mx.Autor \\ correspondiente
}

\author{
Blanco-Jiménez, Mónica \\ Universidad Autónoma de \\ Nuevo León, Profesora \\ investigadora, Pedro Alba $s / n$, \\ Ciudad Universitaria. San \\ Nicolás de los Garza, Nuevo \\ León, México. \\ Moniblanco77@hotmail.com
}

\author{
Guerra-Moya, Sergio \\ Universidad Autónoma de \\ Nuevo León, Profesor \\ investigador, Pedro Alba s/n \\ Ciudad Universitaria. San \\ Nicolás de los Garza, Nuevo \\ León, México. \\ Sagm52@hotmail.com
}

\begin{abstract}
This research aims to determine the factors influencing local supplier development by multinational subsidiaries in emerging countries like México. A quantitative regression methodology is employed using survey data collected from sourcing managers for a case-study focused on Mexico's home appliance value chain. Although the extant literature suggests that a variety of factors influence local supplier development, only three factors were significant in this context: firm size, degree of autonomy, and technological capabilities. The applied research was conducted in the north of Mexico, where more than $50 \%$ of the domestic electrical products are produced; as such, the results generated herein could be reasonably representative of countrywide trends and phenomena. The context and results of this study could be useful to multinational companies in other emerging countries as they pursue development strategies vis-à-vis their local suppliers. Due to the scarcity of studies in México on value chains regarding local supplier development, the research presented here adds important knowledge on this topic.
\end{abstract}

Keywords: Supplier Development, Value Chain, Household Appliances, Multinational companies, autonomy of the firm.

JEL Code: F23, F63

- Citar: Velarde-Moreno, Oscar, Blanco-Jiménez, Mónica, and Guerra-Moya, Sergio (2019). Mexican local suppliers in home appliance value chains. Inquietud Empresarial, XIX (1), 49-61. 


\title{
Proveedores locales mexicanos en la cadena de valor de electrodomésticos
}

\begin{abstract}
Resumen
Esta investigación tiene como objetivo determinar los factores que influyen en el desarrollo de proveedores locales por parte de subsidiarias multinacionales en países emergentes como México. Se emplea una metodología de regresión cuantitativa utilizando datos de encuestas recopiladas por los gerentes de abastecimiento para un estudio de caso centrado en la cadena de valor de electrodomésticos de México. Hallazgos: aunque la literatura existente sugiere que una variedad de factores influyen en el desarrollo del proveedor local, solo tres factores fueron significativos en este contexto: tamaño de la empresa, grado de autonomía y capacidades tecnológicas. La investigación aplicada se realizó en el norte de México, donde se producen más del 50\% de los productos eléctricos domésticos; como tal, los resultados generados en este documento podrían ser razonablemente representativos de las tendencias y fenómenos en todo el país. El contexto y los resultados de este estudio podrían ser útiles para las empresas multinacionales en otros países emergentes, ya que persiguen estrategias de desarrollo con respecto a sus proveedores locales. Debido a la escasez de estudios en México sobre cadenas de valor con respecto al desarrollo de proveedores locales, la investigación que se presenta aquí aporta un mayor conocimiento sobre este tema.
\end{abstract}

Palabras clave: desarrollo de proveedores, cadena de valor, electrodomésticos, empresas multinacionales, autonomía de la empresa

Códigos JEL: F23, F63

\section{INTRODUCTION}

The impact of multinational subsidiaries or Foreign Direct Investment in local economies has been subject of debate for years (Hirshman, 1958). Recently, the researchers and government institutions in México are being attracted to the subject because of the interest on the impact of foreign multinational subsidiaries that operate as an anchor company of a value chain, and more specifically in the local supplier development.

Through time, several researches have surged to measure the impact of multinational subsidiaries in value chains. Some of these investigations measured this impact based on local procurement ratio or the increase in the number of local suppliers
(Driffield and Noor, 1999; Turok 1993; UNCTAD, 2001).

There are other investigations focused in measure the supplier development based on the degree of transfer technology that occurs between the anchor multinational subsidiaries and their suppliers, that is because in theory, Multinational subsidiaries are equipped with better technology and knowhow (Halbach, 1989; UNCTAD, 2001). And finally, there are other studies that centered their attention to economic spillovers caused by FDI inflows, or the influence of multinational subsidiaries in regional development (Blomstrom and Kokko, 2001; Javorick, 2004).

Although several studies on the impact of multinational subsidiaries have been documented in literacy (Blomstrom, Kokko, 
and Zejan, 2000; Giroud, 2003; 2007; Rodriguez-Clare, 1996; UNCTAD, 2001; Alkhatatneh, 2011; Medina, 2016), there is a lot of uncertainty and unpredictability concerning this phenomenon on certain countries and industries.

The following research aims to add further knowledge on the impact of supplier development in Global value chains (GVCs) through multinational corporations and their subsidiaries in Mexico. There are three key reasons for this. First, Mexico was the first Latin American country to receive foreign direct investment. Second, it has developed an important international trade network with the signing of more than 12 free trade agreements with 45 countries, thus significantly increasing its exports. Third and finally, Mexico hosts multinationals that have pursued relatively active development agendas vis-à-vis domestic suppliers.

The purpose of this research is to determine which factors influence local supplier development from multinational subsidiaries in the México home appliance value chain. The literature review suggests that several factors influence local supplier development, namely the size of the subsidiary, degree of autonomy, market orientation, experiences of the multinational subsidiaries in the host country, and the technological level of their products.

To achieve this objective, a description of the home appliance industry value chain will be presented in the next section. This is followed by the development and description of our theoretical framework that focuses on the factors influencing the development of local suppliers in the value chain of multinational companies. We then put forward our survey methodology, with elicitation from the selected population. These primary data are analyzed and explored through a multiple regression analysis. Finally, in the concluding section, we offer summary observations along with recommendations for future research.

\section{HOME APPLIANCE INDUSTRY}

The home appliance industry is a global industry that has experienced an almost $20 \%$ growth in the last four years (Figure 1). This growth is predicted to double over the next four years, to $41 \%$, arriving at an expected production of USD $\$ 599320$ millions in 2020.

This growth is due, in part, to the dynamics of world production. As shown in Figure 2, the main producing region of household appliances is the Asia Pacific,

FIGURE 1 GROSS PRODUCTION VALUES OF THE HOME APPLIANCE INDUSTRY FROM 2013 TO 2020 (USD \$MILLIONS)

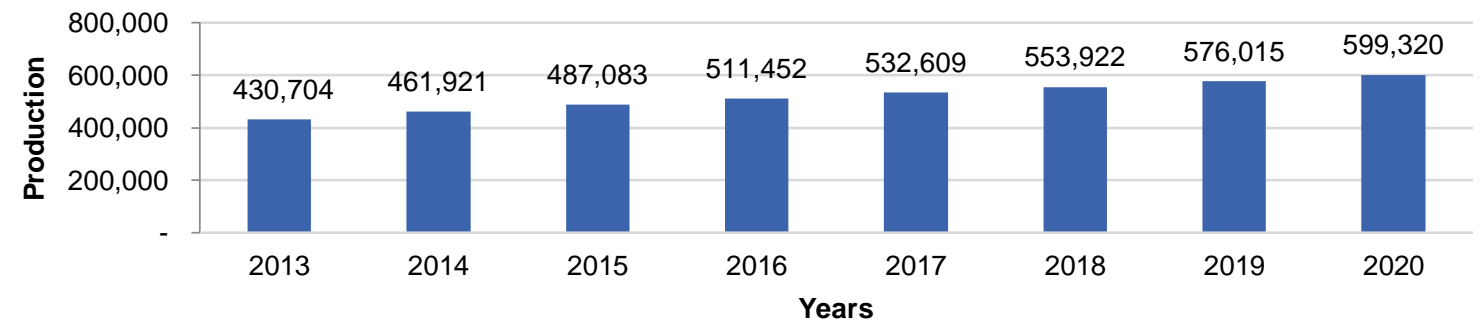

Source: Promexico, 2014 


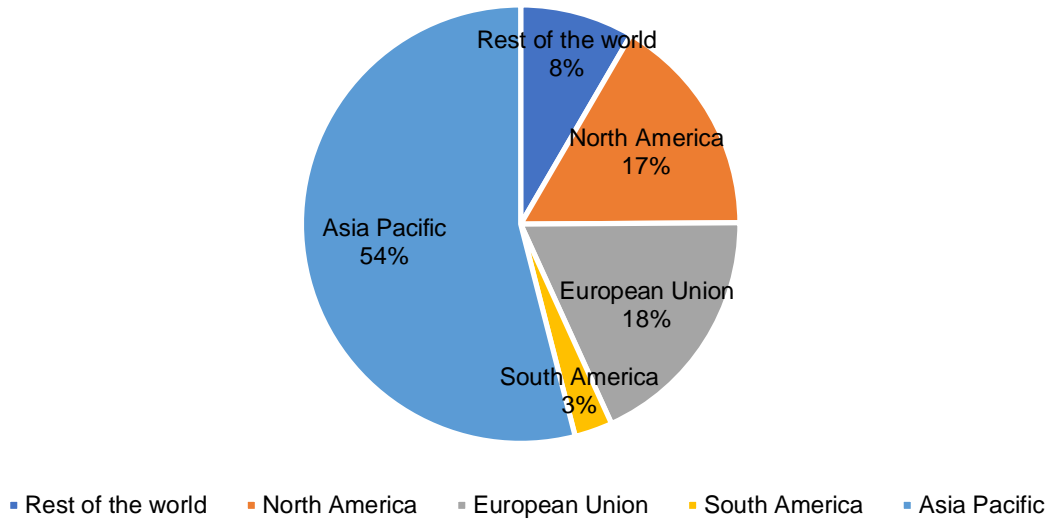

Source: Promexico, 2014

which accounted for about $54 \%$ of total production in 2013, where China and Japan together accounted for $45 \%$ of world production. This is followed by the European Union (with 18\%),

\subsection{The household appliances industry in Mexico}

Mexico is one of the leading exporters of household appliances. In 2012, it was ranked sixth behind China, Germany, Italy, Thailand, and the United States. Gross production in the Mexican home appliance industry increased by $\$ 370$ million from 2014 to 2016 (Figure 3) and it is expected that, in the following years, an annual increase of $3.4 \%$ will be maintained, reaching $\$ 8,755$ million by 2020 .

FiguRE 3. GROSS PRODUCTION OF THE MEXICAN HOME APPLIANCE INDUSTRY FROM 2014 TO 2020 (USD \$MILLIONS)

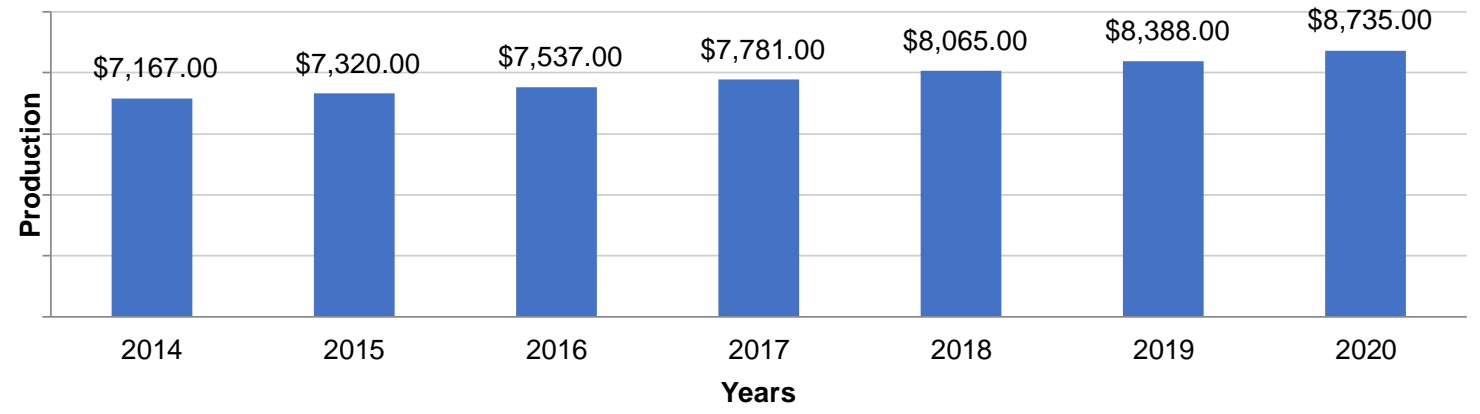

Source: Promexico 2014

Production of household appliances occurs by virtue of the activities of multinational companies in Mexico and the value chain is classified according to the following categories: air conditioning and heating systems, industrial refrigeration, small appliances, and white goods (CELAC, 2016). This value chain can be mapped in terms of three tiers (Figure 4). Tier 3 consists of mining and synthetic resin companies, Tier 2 is constituted by metallurgy, plastics, electric, and electronic component 
manufacturers, and Tier 1 is represented by metallic and plastic manufacturers and electric and electronic assembly manufacturers. Finally, these multinationals produce the following types of final goods: refrigerators, air conditioning and heating goods, washers, stoves, and another household appliance.

Figure 4. HouseHold APPLIANCES' SUPPLY CHAIN MAPPING

Tier 3

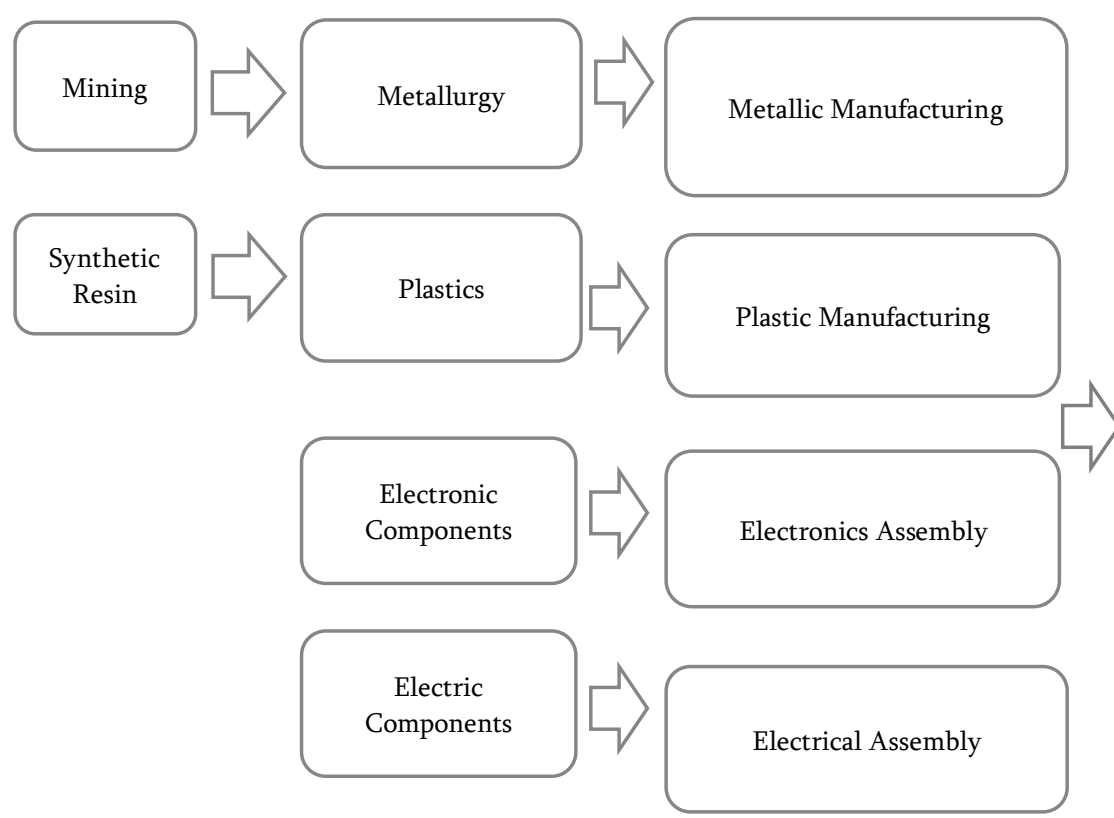

Source: Promexico, 2014

This chain of value in Mexico implies the existence of a large number of suppliers that serve the supply chain from Tier 1 to Tier 2 . For multinational companies, it is essential to have local or national suppliers that meet their requirements in terms of quality, price, and delivery times. Therefore, it is important to emphasize that the value chain of the appliance industry in Mexico is closely linked to local suppliers. According to studies by the Cluster of Appliances of the State of Nuevo León (CLELAC, 2013), in 2012, the local content of the home appliance supply chain in México was $65.5 \%$; for reference, the Mexican automotive industry is associated with a much smaller proportion of local content at only $33.1 \%$ (see Table 1 ). This highly local content is significant in order to understand which factors can boost the local sourcing in other supply chains.

TABLE 1 COMPARATIVE ANALYSIS OF IMPORTED VERSUS LOCAL CONTENT IN MEXICAN INDUSTRIES (USD \$BILLION)

\begin{tabular}{lcccc}
\hline & Gross Production & Imported content & Local content & Local content \% \\
\hline Automotive industry & $\$ 47.8$ & $\$ 32$ & $\$ 15.8$ & $33.1 \%$ \\
Household appliance industry & $\$ 5.8$ & $\$ 2$ & $\$ 3.8$ & $65.5 \%$ \\
\hline
\end{tabular}

Source: CLELAC, 2013 


\section{THEORETICAL FRAMEWORK}

To understand supplier development, it is necessary to be familiar with so-called backward linkages. Hirshman (1958) used this term, focusing on multinational companies that apply internationalization strategies such as foreign direct investment. By penetrating foreign markets, multinational subsidiaries have to obtain inputs and components from local suppliers, i.e., establish backward linkages with such suppliers.

Supply chains characterized by backward linkages allow the integration of suppliers in the production chain of a company (Lall, 1993). In many cases, these inputs come from foreign suppliers or national suppliers. In the literature, one of the ways in which the development of national suppliers is measured is through the local supply chain, in terms of the percentage of national inputs integrated into the company's finished products (Brannon et al., 1990; Turok, 1997).

Extant research has measured the impact of multinational subsidiaries in value chains. Some of these investigations have quantified impacts based on local procurement ratios or the increase in the number of local suppliers (Driffield and Noor, 1999; Turok, 1993; UNCTAD, 2001).

Specifically, reviewing the literature established that some factors that influence multinational subsidiaries to develop and boost local suppliers: the size of the subsidiary, the degree of autonomy, market orientation, the experiences of multinational subsidiaries in the host country, and the technological level of their products.
Proposition 1: Larger multinational subsidiaries are more prone to local supplier development

Some authors have considered the size of the company as a possible factor in the development of local suppliers (Alkhatatneh, 2011; Giuliani, 2008); they point out that larger companies will have more resources to invest time and money in their suppliers.

The study by Giroud (2003) showed that the size of the company influenced the development of the suppliers, where it was found that although large subsidiaries were less oriented to local supply, they establish more significant links compared to their smaller counterparts. The size of the company is usually measured through the number of employees (Alitken and Harris, 1999).

Pous (2005) in his investigations in Costa Rica also found that the size of the firm exhibits a relationship vis-à-vis the development of suppliers. According to that study, larger companies are usually more integrated into an internal network of supplies, which causes them to obtain their inputs from the network. Therefore, capacity with respect to installation, personnel, and financing is a positive function of company size; larger companies are able to develop their own supply chain under the prevailing standards.

Proposition 2: Multinational subsidiaries' with a broader degree of autonomy in a host country are more prone to local supplier development.

The autonomy of a multinational company to select its suppliers is another factor that has been commonly addressed in the literature. Many authors suggest that the 
degree of subsidiaries' autonomy in sourcing decisions can influence the extent of local procurement and supplier development (Dicken, 2003; Iman and Nagata, 2005; Meyer, 2004; Tavares and Young, 2002).

The literature suggests that internationalization processes of multinational companies include assigning procurement roles to their subsidiaries (Giroud and Mizra, 2006). There are two types of roles for these subsidiaries: one where procurement decision-making takes part in the central offices of a company in the foreign country, and another where each subsidiary in a host country possesses a certain degree of autonomy in sourcing decisions (Jindra, 2009).

A previous investigation (Brannon et al., 1990) was conducted in the maquila industry on the northern border of México, where the local content of their finished products was below 2\%. A survey revealed that the most important factor regarding local sourcing for managers and sourcing directors was their degree of autonomy in comparison to their central offices.

Other research carried out in Eastern European countries (Jindra and Giroud, 2009) suggests that firms with greater autonomy should not only be more prone to backward linkages but should also be directly proportional. The results showed that the greater the level of autonomy of a company, the more suppliers are developed.

As UNCTAD (2001) points out, although there is no autonomy of purchasing in subsidiaries established in another country, it is essential that they achieve greater autonomy to have a positive influence on the development of national suppliers. Similarly, for Zanfei (2000), the subsidiaries that successfully develop some suppliers will be given greater autonomy as a result.

Thus, having greater autonomy in purchasing decisions allows you to choose your own local suppliers and develop a supply chain with the advantage of proximity so that monitoring and communication can occur more easily; among other things, this also provides greater flexibility at a time when it is necessary to make changes in the technical specifications of the products.

Proposition 3: The market orientation to exports of multinational subsidiaries discourage local supplier development.

The literature suggests that market orientation of the firm is related to local sourcing. It has been suggested that domestic-oriented subsidiaries develop their local suppliers more often than their exportoriented counterparts (UNCTAD, 2001). Domestic- and export-oriented firms are normally classified depending on how much of their total production is destined for local or foreign markets (Smarzynska, 2004).

Several studies have demonstrated that companies with an export market orientation tend to import components to a larger extent than companies that have a local market orientation (Belderbos et al., 2001; Dicken, 2003). This phenomenon can be due to several factors related to standards of the countries importing these export goods, as well as financial rules and requirements related to the extension of taxes on imports.

Work conducted in Lithuania found that export-orientated subsidiaries generated less backward linkages (Smarzynska, 2004). One of the possible explanations for these results 
is that companies that focus mainly on exports have more stringent requirements and quality standards than companies that dedicate their production to the local market (Alkhatatneh, 2011; Altemburg, 2000).

There is also the suggestion that subsidiary companies generate more competitive and sustainable linkages with their local suppliers compared to exportoriented firms (Altenburg, 2000). In these arguments, it is believed that the extent of market orientation of multinational subsidiaries in a host country influences local supplier development.

Proposition 4: Multinational subsidiaries' Higher technological capabilities discourage local supplier development.

Fuji (2013) delineates products according to their technological sophistication, from very low technological levels observed in terms of products from the food industry, beverages, tobacco, oil products, and wood, up to very high levels in computer equipment and various types of electronics.

The literature also shows that the technological level of the product can also determine the development of domestic suppliers (Fuji, 2013; Moran, 2005). Indeed, studies have shown that the more technologically advanced the product, the lower the national inputs; this is because the greater the technological distance between the company and its supplier, the greater the cost of investing in the supplier, so that it can meet requisite product specifications.

Kennel (2007) notes that the creation of backward linkages is limited when the divergence between the technological capabilities of the multinational company and its suppliers is too large, which sometimes causes local firms to be uncompetitive.

In the case of Scotland, Turok (1997) showed that the technological standards of multinational companies were very high for local suppliers, limiting the growth of backward linkages. Many of the products that were integrated into the production chain of multinationals were low-tech products, such as articles made of wood and paper or some packaging.

In the case of Mexico, Fuji (2013) found that the lower the technological level of finished export products, the greater the integration of domestic inputs. On the other hand, the higher the technological level of export products, the lower was the integration of national inputs.

A study by PROMEXICO (2011) is also important here because it focused on an appliance sector analysis, specifically refrigerator components. This work established the components that are imported and ones that are manufactured and obtained in Mexico; the results showed that the most technologically advanced components, such as electronic boards, were entirely imported.

\section{Methodology}

The type of research employed was exploratory, descriptive, and explanatory, with a non-experimental research design. The measurement instrument is a survey consisting of questions divided into two sections. Section 1 contains 21 of the questions and elicits general information from respondents. The second section contains the remaining 24 questions, all answerable on an intensity scale from 1 to 6 where 1 is never and 6 is always. All 24 
questions formed the basis for the elaboration of 5 constructs (see Table 2).

The description of the Measurement of variables can be observed in Table 2 . The dependent variable is supplier development, which is measured in terms of knowledge transfer, increase of suppliers and increase of linkages.

The independent variables are size of the firm, autonomy of the firm, market orientation of the firm, experience of the firm and the technological capabilities of multinational affiliates. Size of the firm refers to employees, sales, supplier development department size. The autonomy of the firm measures the foreign affiliate autonomy regarding supply decisions (contracts negotiations, degree of freedom selecting new suppliers).

Market orientation of the firm is measured based on market priorities and the destiny of the production of the foreign affiliates (local market, foreign market). The degree of the technological capabilities of multinational subsidiaries is measured in the technological level of inputs, technological level of terminated products and technological knowledge.

TABLE 2. SURVEY STRUCTURE

\begin{tabular}{|c|c|c|c|c|}
\hline Type of question & Variable & $\begin{array}{l}\text { Number of } \\
\text { items }\end{array}$ & Scale & Cronbach's Alpha \\
\hline General Data & & 21 & & \\
\hline Supplier development & Dependent & 5 & Likert 1 to 6 & .874 \\
\hline Size of the firm & Independent & 5 & Likert 1 to 6 & .786 \\
\hline Autonomy of the firm & Independent & 4 & Likert 1 to 6 & .910 \\
\hline $\begin{array}{l}\text { Market orientation of the firm } \\
\text { products }\end{array}$ & Independent & 5 & Likert 1 to 6 & .685 \\
\hline $\begin{array}{l}\text { Technology level of the firm } \\
\text { products }\end{array}$ & Independent & 5 & Likert 1 to 6 & .903 \\
\hline
\end{tabular}

Source: Own elaboration

We surveyed 21 multinational companies that are subsidiaries of the domestic appliance sector and registered in the cluster of household appliances in the State of Nuevo León. They represent the main companies of this sector in Mexico, including MABE, WHIRLPOOL, CRIOTEC, CARRIER, and LG.

\section{RESULtS}

To explain the relationship between independent and dependent variables, a multiple regression analysis was performed. The multiple regression model can be explained by the following equation:

$$
Y_{t}=\beta_{0}+\beta_{1} X_{1}+\beta_{2} X_{2} \beta_{3} X_{3}+\beta_{4} X_{4}+\varepsilon
$$

In this research the dependent variable or $\mathrm{Y}$ is supplier development. The independent variables $\mathrm{X} 1, \mathrm{X} 2, \mathrm{X} 3, \mathrm{X} 4$ are represented by Size, Mrkt_Orient, tech and autonomy respectively. Using the statistical package SPSS, a regression analysis was conducted with the dependent and independent variables. The model summary presented an $\mathrm{R}$ squared of .704, the adjusted $\mathrm{r}$ square which is more precise was .631 therefore a proportion of more than $60 \%$ of the model is explained by the explanatory variables (see Table 3). 
TABLE 3. MODEL SUMMARY.

\begin{tabular}{|c|c|c|c|c|c|c|c|c|c|}
\hline \multirow[t]{2}{*}{ Model } & \multirow[t]{2}{*}{$\mathbf{R}$} & \multirow[t]{2}{*}{ R Square } & \multirow{2}{*}{$\begin{array}{c}\text { Adjusted R } \\
\text { Square }\end{array}$} & \multirow{2}{*}{$\begin{array}{l}\text { Std. Error of } \\
\text { the Estimate }\end{array}$} & \multicolumn{5}{|c|}{ Change Statistics } \\
\hline & & & & & $\begin{array}{l}\text { R Square } \\
\text { Change }\end{array}$ & F Change & $\mathrm{df1}$ & df2 & $\begin{array}{l}\text { Sig. F } \\
\text { Change }\end{array}$ \\
\hline 1 & .839 & .704 & .631 & .64754 & .704 & 9.536 & 4 & 16 & .000 \\
\hline
\end{tabular}

Source: own development

In terms of the regression analysis, we first note that all variance inflation factors (VIFs) are below 10, which suggests that collinearity between the independent variables is never substantial enough to risk biasing coefficient standard errors in our empirical context. However, in terms of coefficient estimates, it can be seen that only three variables, size of the firm, autonomy of the firm, and market orientation of the of firm's products are significant since their $\mathrm{p}$ values are less than .05 (as shown in table 4).

TABLE 4. ESTIMATION RESULTSA.

\begin{tabular}{|c|c|c|c|c|c|c|c|c|c|c|c|}
\hline \multirow{2}{*}{\multicolumn{2}{|c|}{ Model }} & \multicolumn{2}{|c|}{$\begin{array}{l}\text { Unstandardized } \\
\text { Coefficients }\end{array}$} & \multirow{2}{*}{$\begin{array}{l}\begin{array}{l}\text { Std. } \\
\text { Coef }\end{array} \\
\text { Beta }\end{array}$} & \multirow[t]{2}{*}{$\mathrm{T}$} & \multirow{2}{*}{$\begin{array}{c}\text { Sig. } \\
\text { p- } \\
\text { value }\end{array}$} & \multicolumn{3}{|c|}{ Correlations } & \multicolumn{2}{|c|}{ Collinearity Statistics } \\
\hline & & $\mathrm{B}$ & $\begin{array}{c}\text { Std. } \\
\text { Error }\end{array}$ & & & & $\begin{array}{l}\text { Zero- } \\
\text { order }\end{array}$ & Partial & Part & Tolerance & VIF \\
\hline 1 & (Constant) & 1.212 & .891 & & 1.361 & .192 & & & & & \\
\hline & Size & .574 & .161 & .559 & 3.560 & .003 & .655 & .665 & .484 & .750 & 1.333 \\
\hline & Mrkt_Orient & -.578 & .242 & -.473 & -2.384 & .030 & -.229 & -.512 & -.324 & .469 & 2.134 \\
\hline & Tech & .239 & .154 & .312 & 1.555 & .140 & -.196 & .362 & .211 & .459 & 2.181 \\
\hline & Autonomy & .402 & .142 & .445 & 2.825 & .012 & .656 & .577 & .384 & .745 & 1.342 \\
\hline
\end{tabular}

Source: own development

\section{DISCUSSION}

Size of the firm presented mixed results on previous studies. There were several investigations in New Zealand, Poland, México and Jordan with non-significant results. However, a research on United States was conducted (Liu, 2010) were the size of the firm resulted significant as in this investigation. There is a strong argument that in industries were suppliers can meet the supply demand of larger companies, the size of the firm can influence supplier development (Liu, 2010), and therefore there could be an argument that in Mexico,
Two of these coefficients, Autonomy and Size are positive and, hence they positively influence supplier development as predicted by the hypothesis. However, Mrkt_Orient had a negative impact on supplier development according to the results which is contrary to the relationship expected by the previously established hypothesis. On the other hand, Tech was the only nonsignificant independent variable of the model. 
industry, besides a previous interview conducted prior the elaboration of the measurement industry suggested that most companies on this sector had high degrees of autonomy.

In previous studies, Market orientation of the firm was significant in countries as Malaysia, Catania, Jordan, Costa Rica and some other European countries. The results of this investigation suggest that an orientation to foreign markets fostered the local supplier development instead of discouraging it. A possible explanation for this is that the main market of the home appliance exportations of multinational firm based in México are the United States, which is a well-known market for this particular country and also has a free trade agreement.

Technological capability of the firm was non-significant which was contrary to the results obtained by Medina (2016) and Turok (1997), in Costa Rica and Ireland, where technological gaps affected supplier development through backward linkages. Although, there is some likelihood that the reason explaining why technology is not an issue in this particular industry is due the fact that there is no technological gap between subsidiaries and local suppliers, and perhaps that's one of the main reasons of the higher level of local content in the home appliance value chain compared to other GVCs in México.

\section{CONCLUSION}

The first part of this article showed the importance of the domestic appliance industry, which is expected to grow considerably in the coming years. Asian countries are the main producers of these products, followed by North America and Europe. Mexico is not only one of the six main exporting countries for these products, but has also witnessed a constant growth in the production of appliances in recent years with the establishment of subsidiaries of the main multinational companies, such as MABE, WHIRLPOOL, CRIOTEC, CARRIER, and LG. More than 50\% of the electrical appliances produced in Mexico originate specifically from Nuevo Leon; as such, the results herein can be expected to be generalized reasonably to country-level trends and phenomena.

Regarding the home appliance value chain, it is interesting to observe the dynamics of Tier 1, 2, and 3 companies, and how Mexican companies in each of these channels allow supplying the subsidiary companies in Mexico. Since this sector exhibits levels of local or national integration of up to $65.5 \%$, this allows significant vertical integration and competitive advantage. This shows that although Mexico is an emerging country, it has a sound infrastructure network, trained personnel, suppliers, customers, and government agencies that focus on the integration of value chains for this industry.

Because the multinational subsidiaries of this sector in Mexico are exemplary vis-à-vis the high levels of development of their local suppliers, such a case-study could provide useful transferable insights for multinational companies from other emerging countries that wish to better develop their local suppliers. It is important to highlight the collection of theories, studies, and practical cases that enabled us to theoretically demonstrate the factors such as firm size, the degree of the autonomy of purchase, the internal or external market's orientation, the 
experience in time, and the technological capabilities of multinational company's influence on the supplier management chain that can be taken into account by other multinational companies.

Also, this research shows results of the surveys that were conducted - not all factors were significant for the development of local suppliers in Mexico, as an emerging country. The main factors that influence the development of local suppliers in Mexico are as follows: the size of the company; this is because, the larger the production lines and the number of orders, the greater is the need to obtain various suppliers. The autonomy of the company is the other significant factor since it is important that the subsidiaries in the country are in charge of finding and selecting the local suppliers because they have a direct contact with them and can closely monitor the necessary requirements to improve the competitiveness of its products.

For future research it would be convenient to carry out the same study in different value chains of the state of Nuevo León, since there are up to eight Global value chains in the state, in addition a comparative study could be done. The study could help identify whether technology is a factor that influences supplier development in other industrial sectors.

\section{REFERENCES}

Aitken, B. J., and Harisson, A.E. (1999), Do domestic firms benefit from direct foreign investment? Evidence from Venezuela, American Economic Review, 89(3), 605-618.

Alkhatatneh, T.A. (2011), Technology transfer from foreign firms to local suppliers through backward linkages in Jordan. Doctoral thesis, The University of Huddersfield.

Altenburg, T. (2000). Linkages and spill-overs between transnational corporations and small and medium-sized enterprises in developing countries: Opportunities and policies. Retrieved from: http://edoc.vifapol.de/opus/volltexte/2013/4041/pdf/BuG 5_2000_EN.pdf

Battat, J., Frank, I., and Shen, X. (1996). Suppliers to multinationals: Linkage programs to strengthen local companies in developing countries. The World Bank.

Belderbos, R., Capannelli, G. and Fukao, K. (2001), Backward vertical linkages of foreign manufacturing affiliates: Evidence from Japanese multinationals, World Development, 29(1), 189-208.

Blomstrom, M., Kokko, A. and Zejan, M. (1994), Host country competition, labour skills, and technology transfer by multinationals, Review of World Economics, 130(3), 521-533.

Brannon, J. T., James, D. D., and Lucker, G. W. (1994). Generating and sustaining backward linkages between maquiladoras and local suppliers in Northern Mexico. World Development, 22(12), 1933-1945.

Castellani, D., and Zanfei, A. (2002). Multinational experience and the creation of linkages with local firms: evidence from the electronics industry. Cambridge Journal of Economics, 26(1), 1-25.

CLELAC, (2013) Cluster de Electrodomésticos del Estado de Nuevo León CLELAC. Retrieved from: http://www.clelac.org.mx/images/stories/estadisticasnl/Pe sentaci\%C3\%B3n\%20CLELAC\% 20junio\%202013 .pptx.zip

CLELAC, (2015) Cluster de electrodomésticos del estado de Nuevo León CLELAC. Retrieved from: https://web.archive.org/web/20160319173353/http://clela c.org.mx/como-trabajamos.php

Dicken, P. (2003), Global Shift, Reshaping the Global Economic Map in the 21st Century, Fourth Edition, SAGE Publications Ltd.

Driffield, N. and Noor, A.H.M. (1999), Foreign direct investment and local input linkages in Malaysia, Transnational Corporations, 8(3), 1-25.

Fujii, G. y R. Cervantes (2013), México: valor agregado en las exportaciones manufactureras, Revista cepal, 109,pp 143158.

Giroud, A. and Mirza, H. (2006), Multinational enterprises and local input linkages in Southeast Asia, Transnational Corporations, 15(3), 1-32.

Giroud, A. (2003), Transnational Corporations, technology and economic development: Backward linkages and knowledge transfer in South East Asia, Cheltenham, Northampton: Edward Elgar.

Giroud, A. (2007), MNEs vertical linkages: the experience of Vietnam after Malaysia, International Business Review, 16(2), 159-176. 
Giuliani, E. (2008), Multinational Corporation and Patterns of local Knowledge Transfer in Costa Rican HighTechnologies, Development and Change. 39(3), 385-407.

Halbach, A. J. (1989), Multinational enterprise and subcontracting in the third world: a study of interindustrial linkages." Geneva: ILO, International Labour Office Multinational Enterprises Program. Working paper No. 58.

Hirschman, A. (1958), The Strategy of Economic Development. New Haven, CT.

Ikuho, J.C.R. and Rodríguez, R. A. (2011), Vertical Integration or Disintegration? A Bargaining Model of the Maquiladora's Case. Nóesis. Revista de Ciencias Sociales y Humanidades, 21(41), 101-118.

Iman, M. and Nagata, A. (2005), Liberalization policy over foreign direct investment and the promotion of local firms' development in Indonesia, Technology in Society, 27(3), 399-411.

Javorcik, B.S. (2004), Does foreign direct investment increase the productivity of domestic firms? in search of spillovers through backward linkages, American Economic Review, 94(3), 605-27.

Jindra, B. Giroud, A. and Scott-Kennel, J. (2009), Subsidiary roles, vertical linkages and economic development: Lessons from transition economies, Journal of World Business, 44(2), 167-179.

Kumar, N. 1998, Multinational enterprises, regional economic integration, and export-platform production in the host countries: an empirical analysis for the US and Japanese Weltwirtschaftliches Archiv. 134(3), 450-483.

Lall, S. (Ed.). (1993). Transnational corporations and economic development (Vol. 3). Taylor \& Francis US.

Meyer, K. E. (2004), Perspectives on multinational enterprises in emerging economies, Journal of International Business Studies, 35(4), 259-277.

Medina, M. C. (2016). Encadenamientos productivos y contenido local en empresas de Zona Franca de Costa Rica. Tesis Doctoral, Universidad de Chile

Paus, E. (2005), Foreign Investment, Development, and Globalization. Can Costa Rica Become Ireland? Basingstoke: Palgrave-Macmillan.

Pro México (2014), Electrodomésticos. Retreived from http://www.promexico.mx/documentos/diagnosticossectoriales/electrodomesticos.pdf

Pro México. (2011), Electrodomésticos. Retrieved from, de:http:/www.promexico.gob.mx/es_us/promexico/Elect rodomesticos2

Rodriguez-Clare, A. (1996), Multinationals, Linkages, and economic development, American Economic Review, 86(4), 852-873.
Scott-Kennel, J. (2007), Foreign direct investment and local linkages: An empirical investigation. Management International Review, 41(1),1-27.

Smarzynska, B. (2004). Does foreign direct investment increase the productivity of domestic firms? In search of spillovers through backward linkages. American economic review, 94(3), 605-627.

Tavares, A. and Young, S. (2002), Sourcing patterns of multinational subsidiaries in Europe: testing the determinant. University of Central Lancashire, UK.

Turok, I. (1997), Linkages in the Scottish electronics industry; Further evidence. Regional Studies, 31(7) 705-711.

Turok, I. (1993), Inward investment and local linkages: How deeply embedded is 'Silicon Glen'?, Regional Studies, 27(5), 401-417.

UNCTAD (2001), World Investment Report. Promoting Linkages. Geneva and New York: United Nations Conference on Trade and Development. Retrieved from: https://unctad.org/en/Docs/wir2001_en.pdf

Vernon, R. (1966), International investment and international trade in product cycle: the case of US firms. Quarterly Journal of Economics 80, 190-207.

Zanfei, A. (2000), "Transnational firms and the changing organization of innovative activities", Cambridge Journal of Economics, 24, 515-542. 